\title{
The Bloomsbury Short Story
}

\author{
Ira Nadel $^{1}$
}

Received: 30 November 2016/Accepted: 20 December 2016/Published online: 20 February 2017

(c) The Author(s) 2017. This article is published with open access at Springerlink.com

\begin{abstract}
This article examines the importance of the short story form for the Bloomsbury writers and how their aesthetic theories influenced its composition, structure and content. Often overlooked in the history of the genre, the Bloomsbury short story has a claim to be an important aspect of the twentieth-century accounts of the short story form. Attention to Virginia and Leonard Woolf, Katherine Mansfield, Vita SackvilleWest, E.M. Forster and others, such as Arnold Bennett and D.H. Lawrence, indicates their widespread engagement with the genre and the ways in which they treated it from fragmented conversation, as in Woolf's "The String Quartet," to Foster's employment of linear narrative detail in "The Road from Colonus." Formal experiments with syntax, imagery, and vocabulary and prose rhythm exhibit the seriousness of the short story for Bloomsbury authors. The influence of the Russians is particularly important with Chekov dominating the reading and writing of Woolf, Mansfield, Lawrence and others. The very form of publication - mostly journals and magazines - is also crucial in shaping the length and structure of the short story. Attention to experimentation, as well as renewal, of the genre balances the impact of the short story on writers today and the question of a successor to the efforts and achievements of Bloomsbury's authors. A reading of the short stories of Julian Barnes explores this possibility.
\end{abstract}

Keywords Short story · Bloomsbury · Virginias Woolf · Katherine Mansfield · D.H. Lawrence

Circumstances still hypnotise me.

Katherine Mansfield, 19 October 1922

Ira Nadel

nadel@mail.ubc.ca

1 Department of English, University of British Columbia, 397, 1873 East Mall, Vancouver, BC V6T 1Z1, Canada 


\section{Introduction}

The Bloomsbury short story has been both recognized and neglected. Accounts of individual authors, whether Virginia Woolf, Vita Sackville-West or Katherine Mansfield acknowledge their persistent interest in the short form but rarely engage with its history or development. Questions of style are almost never addressed, while its relationship to modernism is always overlooked. Similarly, histories of the twentieth-century short story almost never address the short story among this group of writers.

The following essay attempts to correct that imbalance by identifying and analyzing the properties of the formal and cultural elements of the short story at the hands of the Bloomsbury writers. That the Hogarth Press, founded by Leonard and Virginia Woolf in 1917, began with a short story collection is telling. So, too, is the early and sustained success of Katherine Mansfield's writing which began with her In a German Pension (1911) indicating a new internationalism: a New Zealand writer living in England with stories set in Germany. The public's interest in the form, anticipated by the popularity of writers like Kipling, Bennett and even D.H. Lawrence attest to its importance but when experiment, narrative originality and radical characterizations appeared, it startled a complacent readership. Bloomsbury led this change absorbing the influence of a series of Russian writers beginning to appear in English at this time: Tolstoy, Dostoevsky and, more importantly, Pushkin, Gogol, Turgenev and Chekhov.

Preceded by Henry James, Robert Louis Stevenson and Joseph Conrad, the short story form for the Bloomsbury writers was already an accepted and welcomed genre. But the stability of its structure, drawing from conventional elements like dramatic incident, unusual setting and a clear-cut conclusion were about to change. Rather than "The Body Snatcher" (Stevenson), or The Jungle Book (Kipling), new titles such as "Monday or Tuesday" (Woolf) or "Bliss" (Mansfield) suggested a different focus and alternate concern.

Rather than continue the plot-driven style of the Victorian and late Victorian short story emphasizing description and resolution, Bloomsbury short story writers de-emphasized the former and eliminated the latter. Instead of detail, one had impression; instead of a conclusion, one had continuation, even if the text ended. Woolf made these associations clear when she relates the satisfaction of Clarissa Dalloway sewing to the movement of the sea or allows Rhoda in The Waves to see a summer month as a color: "June was white. I see the fields white with daisies, and white with dresses, and tennis courts marked with white" (2008, p. 50). One should in fact describe a summer day not by offering detail but gesture or impression: instead of describing the features of the day, a character in a room should merely turn her head and look out the window and remark, "what a lovely day." "We melt into each other with phrases" is Rhoda's summary of Woolf's technique (2008, p. 11). And instead of an ending, a story should be able to indicate continuation: Mr. Ramsay's arrival at the lighthouse in To the Lighthouse is alternately a beginning as well as an ending. 
But what form did the Bloomsbury short story take and how did it differ from others written at the time? Did Bloomsbury writers like Virginia Woolf, Leonard Woolf, Katherine Mansfield, Vita Sackville-West and E.M. Forster enact a certain short story style? And if so, what are its characteristics?

Accounts of the modernist short story have often ignored Bloomsbury in the evolution of the form, although writers like Woolf, Mansfield and Forster contributed importantly to the genre. Histories such as John Bayley's The Short Story-Henry James to Elizabeth Bowen (1988) or Chares May's The Short Story: The Reality of Artifice (1995) acknowledge, but do not analyze or even identify, the formal contribution of the Bloomsbury group. Dominic Head in The Modernist Short Story (1992) presents a fuller account, yet without the insight offered earlier by G K. Chesterton. In his 1906 study of Dickens, he noted that

Our modern attraction to the short story is not an accident of form; it is the sign of a modern sense of fleetingness, and fragility. It means that existence is only an impression, and, perhaps, only an illusion. We have no instinct of anything ultimate and enduring beyond the episode. (1906, p. 85)

Chesterton is identifying the modernist distrust of certainty, repeatedly outlined in the writing of Bloomsbury. Life as a fleeting, fragile "impression" finds recurrent treatment in the Bloomsbury short story which stresses what Woolf would call "moments of being," a phrase from her autobiographical essay "A Sketch of the Past" (1985, p. 73). The complexity and brevity of contemporary life expressed in the short fiction of Bloomsbury meant experience as a set of episodes stressing the contingency of modern existence conveyed in forms that duplicate that condition.

The short story has generally lacked theoretical discussion, the genre easier to describe than define. Early accounts were only historical, while Henry James, Thomas Hardy or even Joyce never theorized their treatment of form or structure. James, however, offered the most potential for analysis because he provided his own commentary on his work via his prefaces to the 24 volume 1907-1709 New York Edition of his writings. His focus, however, was on the origin of his stories rather than their conceptual elements. Similarly, Hardy and Joyce: they avoided as much as possible commentary on their method and its meta-narrative dimension.

Earlier, in his "At the End of the Passage" (1890), Kipling metaphorically anticipated a shift in the genre. An unknown horror causes the unexpected death of a civil servant at an Indian outstation. Haunting the district doctor who views the body is the story that his dead colleague witnessed terrible things in his dreams. Obsessed with this idea, the doctor photographs the dead man's eyes which are open and staring wildly - but once he develops the negatives, the doctor cannot bear to look at them and destroys the images and any physical proof of the terror. This erasure of the physical evidence underlines the power of psychological sight which Bloomsbury emphasized and Woolf, in particular, developed through her own emphasis on eyes and seeing. "An Unwritten Novel" (1920), for example, is entirely preoccupied with sight, the narrator remarking that "Life's what you see in people's eyes" (2008e, p. 18). Woolf's "Kew Gardens" (1919) reinforces the shift to the psychological with its focus on the movement of figures walking past a flowerbed, the reader dipping in and out of the passing, fragmented conversations while gaining 
insight into the relationships. Woolf mixes the colors of the flower petals floating to the ground with the random thoughts and movements of the visitors. Color, shape and action dominate the narrative.

Bloomsbury short story writers developed a common, or at least mutual, aesthetic that united their work defined by a self-conscious use of form, reliance on abstract language and expression of indirect action. From Woolf's early experiments such as "The Mark on the Wall" (1917) to the writing of E.M. Forster and his often obscure, or incompletely defined actions, this approach lasted. Downplaying plot meant an intensification of thought as expressed by the characters. What the Bloomsbury short story writers shared was an awareness and determination to show consciousness as both evolving and challenged.

While commentary on individual Bloomsbury authors, whether Virginia Woolf, Katherine Mansfield, or E.M. Forster exists, there has been no attempt to unify their representation of character, setting or even time in the short story. Critics have treated the modernist impulses of these writers, who foregrounded literary technique and emphasized ambiguity, uncertainty and conflicting voices, independently. Yet the writers shared several short story methods that collectively define a similar approach beginning with narrative refraction, the term meaning the deflection of light or sound or even an idea from a straight path. In the Bloomsbury short story, the inventions of Woolf, the impersonality of Katherine Mansfield and the implied actions of Forster all contribute to a "refractionary" style marked by indirect or deflected insight—recalling Polonius' advice to his son Laertes in Hamlet: "By indirections find directions out" (2002, p. 1358). Significant detail, which traditionally defines the short story, becomes psychological if not abstract for Bloomsbury's practitioners. The following expands these ideas allied with the powerful influence of Russian writers, especially Chekov, before considering the legacy of the Bloomsbury short story.

\section{Form and Style}

The Bloomsbury short story was less a puzzle or event, as Conan Doyle emphasized with his Sherlock Holmes stories, frequently relying on logic, science and deduction, than an experience undergone and understood by intuition or imagination. The apprehension of an incident or event became its principal technique. Symbol or innuendo revealed more than direct action as in Katherine Mansfield's "Her First Ball" (1921) where a conversation between a young woman and an older man suddenly triggers premonitions of death. Dance offers a parallel; in the words of the critic Arthur Symons in his essay "The World as Ballet" (1899), "nothing is stated, there is no intrusion of words used for the irrelevant purpose of describing" (1899, p. 348). Emotions, ideas and even prejudices are performed, not related to the reader. The moral instruction of the short story, earlier dominating the genre, gives way to an emphasis on technique and a recognized but not unwelcomed inconclusiveness.

The modern contraction of time and space furthermore made the short story genre, especially as practiced by Bloomsbury writers, the most direct representation 
of "existence" as "an impression," conveyed through their experiments with form. The writers created fragmented, ambiguous narratives often focusing on characters outside the mainstream anticipated by, perhaps, Dostoevsky's "White Nights" which concentrates on the underside of St. Petersburg or Kafka's "Metamorphosis." For the Bloomsbury authors, the short story combined the nature of the outsider with more experimental means of rendering psychological understanding.

Contributing to this focus on form was the genre's encouragement of stylization, an emphasis on more expressive but simplified practices. Authorial distancing was part of this shift, almost a pre-requisite allowing for a concentration on detail, expression and feeling evident in Bloomsbury writers and seen, for example, in Woolf's "The Mark on the Wall." An intentional gap between the author and character, a gap repeatedly emphasized for the reader, also underscored the stylized form. This may occur through the absence of names, action deciding what a person is rather than who he or she is. Katherine Mansfield does this in her collection In a German Pension (1911) where types appear as "the Frau," or "the Young Man" without individualized names.

An additional irony of the genre that the Bloomsbury writers understood was the acceptance of its limitations. The short story no longer tried to escape its circumstances attempting to be something it was not. Rather, it intensified its expressiveness precisely because of its boundaries. As a consequence, the short story capitalized on its precision and brevity, while shifting in purpose from narrative and action to impression and sensation. It fixed a moment as if it were a picture or photograph. Woolf quickly perceived this, writing of the painter Walter Sickert that it is difficult to look as his paintings "and not invent a plot, to hear what they [the figures] are saying." The exhibition, she writes, is "full of pictures that might be stories" (1934, p. 13). It is no surprise then that a reviewer of Woolf's early collection Monday or Tuesday (1921) remarked of the title story that she tried "to do in words what can only be done in music or painting" (in Licence 2015, p. 226).

The method of publication contributed to adjustments in the short story form: for the most part, short stories appeared in periodicals. The discursive frame for reading them demanded brevity and clarity, the numerous magazines and journals of the late nineteenth and early twentieth centuries providing ideal vehicles for the reception and shape of the genre. The Strand magazine was where many of the Sherlock Holmes stories first appeared, while Rhythm, the journal edited by John Middleton Murry and Katherine Mansfield, was home to various experimental works. Periodical publication encouraged and determined the innovative forms of the short story. ${ }^{1}$ Nevertheless, analysis of the short story as defined by the Bloomsbury writers has largely been overlooked. ${ }^{2}$

\footnotetext{
1 Two helpful titles on the short story and print form are The Economy of the Short Story in British Periodicals of the 1890s (Chan 2007) and Time and the Short Story (Chialant and Lops 2012).

2 The Cambridge Companion to The Bloomsbury Group (Rosner 2014), for example, contains no discussion of the short story genre. There are, however, individual essays on Woolf and the genre. See Reynier (2003) and Hunter (2007). Hunter, in particular, argues that Woolf's ability to control the means of publication though her Hogarth Press governed the nature of her short story experiments.
} 


\section{Russian Woolf}

Virginia Woolf's view of the Russians is a starting point, her response in part a reaction against the more unadventurous writing by Thomas Hardy, Arnold Bennett, Rudyard Kipling, Somerset Maugham or even H.G. Wells. Indeed, Chekhov, Turgenev and Dostoevsky-along with Soviet cinema-became the models of Woolf's short story method and that of Bloomsbury. ${ }^{3}$ She and other Bloomsbury writers created a series of disruptive metafictions that destabilized narratives, creating inconclusive situations originating, first, with the Russians. The equivocal nature of life became her refrain, asking at one point in her Diary "now is life very solid or very shifting? I am haunted by the two contradictions" (1980, p. 218). The narrator observes this very dilemma in Woolf's short story, "The Lady in the Looking-Glass: A Reflection" (1929). Inside a house everything changes, and outside it stays the same. On the interior, lights and shadows compete with shifting human action: "the room had its passions and rages and envies.... nothing stayed the same for $2 \mathrm{~s}$ together" (2008, p. 63). In the garden outside, reflected in the looking glass, nature seems still.

The Russians anticipated this duality, sensing the union between the trivial and the universal which Woolf understood. When she reviewed Constance Garnett's translation of Chekhov's The Bishop and Other Stories in 1919, Woolf wrote of "The Steppe" that "as the travellers move slowly over the immense space, now stopping at an inn, now overtaking some shepherd or waggon, it seems to be the journey of the Russian soul" (1988, p. 85). Her reading sees beyond the immediate action and accepts, if not celebrates, the indecisiveness of the story arguing that "inconclusive stories are legitimate" leaving us with reflection and speculation (1988, p. 84). Chekhov, she suggests, is like a peasant in "The Steppe" who could "see the fox lying on her back playing like a dog far in the distance where no one else could see her" (1988, p. 84).

One other vital feature of the short story for Woolf was its brevity. In a July 26, 1917, letter to David Garnett after he praised "The Mark on the Wall," her contribution to Two Stories, and the first publication of the Hogarth Press, she writes that

in a way its easier to do a short thing, all in one flight than a novel. Novels are frightfully clumsy and overpowering of course.... I daresay one ought to invent a completely new form. (1976, p. 167)

Shortness and inventiveness unite. She would later tell Ethel Smyth of her excitement with the short story as offering an alternative to the conventional method of the novel; in writing "An Unwritten Novel," she found in one second "how I could embody all my deposit of experience in a shape that fitted it" (1979, p. 231). Part of that shape was incorporating a new "plotlessness" and freedom from narrative inevitability. The elliptical suddenly had meaning.

\footnotetext{
3 Woolf reviewed Dostoevsky's An Honest Thief and Other Stories in the Times Literary Supplement of 23 October 1919. See McNeillie (McNeillie 1987). She also reviewed work by Chekhov and Turgenev and published her essay "The Russian Point of View" in The Common Reader. Andrew McNeillie (McNeillie 1987). It combines two earlier essays: "The Russian View" and "Tchehov's Questions."
} 
What Woolf reacted to were certain markers of status and identity that dominated realistic short stories. Confronting this was a new, interrogative sense of meaning, originating in Chekhov, which soon appeared in her writing. In Chekhov, she explained in "The Russian Point of View,"

half the conclusions of fiction fade into thin air; they show like transparencies.... the general tidying up of the last chapter, the marriage, the death... become of the most rudimentary kind. (1986, p. 185).

Let us not manipulate evidence, she argues to "produce something fitting, decorous, agreeable to our vanity." She repels the need for authoritative acts of narration which the short story encourages.

Adding to her sense of experimentation was film, and the impact of cinema on her short stories is critical. Woolf had a long-standing interest in film, and her work repeatedly exhibits montage, close-ups, flashbacks, tracking shots and rapid cuts associated with Soviet cinema in the 1920s and 1930s as it moved from the silent to sound era. This is evident in Woolf's "The String Quartet:"

Well, here we are, and if you cast your eye over the room you will see that Tubes and trams and omnibuses, private carriages not a few, even, I venture to believe, landaus with bays in them, have been busy at it, weaving threads from one end of London to the other. Yet I begin to have my doubts - (2008b, p. 35).

The reader becomes a camera consciously alternating between the immediate and the distant, weaving a duality of vision that simultaneously includes and excludes.

"The Mark on the Wall" and "Kew Gardens" each open as a sequence of film shots. This is not unexpected: by June 1926, Woolf was often writing about the new genre citing newsreels, feature films and avant-garde cinema, objecting to action dominating movement, her essay "The Cinema" appearing that year in The Nation and Athenaeum. What emerges in her short stories is an experimental cineplay using visual images to express emotions (as seen in Soviet silent cinema), while animating objects into a kind of life. The Italian mirror in "The Lady in the Looking Glass" (2008) plays exactly this role as both the vehicle for, and object of, transformation much like a movie projector. This is perhaps no surprise: in 1929 she attended a showing of "Storm over Asia" by Vsevolod Pudovkin in Berlin, one of the last major Soviet silent films which displayed these features. Montage, used repeatedly in the film, was a hallmark of the silent cinema, a rapid and often unrealistic style of unexpected cuts from scene to scene linked visually or emotionally, but not logically.

Woolf's forty-six stories, of which only eighteen were published in her lifetime, were mostly written between two novels and conceived of as a pause, or entertainment, or even as a way of making money. ${ }^{4}$ But collectively, they represent experimentation in form and technique à la Samuel Beckett. The short stories are

\footnotetext{
4 The Hogarth Press published a good number of Woolf's short stories, including Leonard Woolf's posthumous collection of her work, A Haunted House and Other Short Stories (Woolf 1942). The press also published short stories by Leonard Woolf, Katherine Mansfield, Ivan Bunin and other writers.
} 
alternately in dialogue with her longer works but also free from them. "Kew Gardens" (1917) is an early, almost Vorticist example of her play with language and tone, extended in her "Blue and Green." The opening of "Green" - "the pointed figures of glass hang downwards. The light slides down the glass, and drops a pool of green"-is not very far from Beckett's "Fizzle 7: Still" which begins with "Bright at last close of a dark day the sun shines out at last and goes down" (2008a, p. $33 ; 1995 a$, b, p. 240). ${ }^{6}$

Woolf's interest in reflection again anticipates Beckett's concern with self-image and representation seen clearly in his own movie, Film. Woolf's early "Phyllis and Rosamond" or "The Evening Party" (unfinished) further connect with Beckett, especially with their use of "inconsecutive conversation," a hallmark of Beckett's prose and dramatic writing (Randall 2013, p. 101). And there is an aspect of Woolf in Beckett's admission to his biographer James Knowlson that Joyce "had gone as far as he could in the direction of knowing more" but that his own way forward was not in putting in but "taking away" (in Martin 2014). Woolf and Beckett both favored economy and preferred angled or displaced narratives emphasizing the emergence rather than the report of a story. Substituting for plot and explicit judgment is method, linked to the immediate but ordinary experience of the characters. The reader's job is to transform these moments into meaning demonstrated earlier in Chekhov or Turgenev.

\section{Russian Mansfield}

Katherine Mansfield recognized this in the Russians as well as Woolf. Of Chekhov's "The Steppe," she remarked that the story did not become immortal but "always was," partly because it had "no beginning or end." Chekhov "touched one point with his pen... and then another point: enclosed something which had, as it were been there for ever" (1977, p. 137).

This notion of enclosing experience stands as a key principle of the Bloomsbury short story, if not the modernist project - think of Joyce enclosing a single day, June 16, 1904, or Woolf's Mrs. Dalloway, a single day in Clarissa Dalloway's life or even Yeats, a single event in "Easter 1916." Enclosing experience is also the aim of Beckett: "don't pretend to seek, don't pretend to think, just be vigilant" he asserts in "Texts for Nothing, 5" (1995, p. 117). But enclosure also permits an opening out, allowing experience to radiate outward beyond the immediate experience: Yeats is able to include a list of those sacrificed to the cause of Independence; Winnie, entrapped up to her neck in sand in Act II of Happy Days, nonetheless elaborates her life with her husband Willie. Shakespeare may here be a guide because, as Woolf

\footnotetext{
5 On rare occasions, Woolf wrote several short stories after she completed a novel, the clearest example following Mrs. Dalloway (1925). Her stories explore a party psychology which greatly interested Woolf (see "The Evening Party" [1918]), as it did Katherine Mansfield who also uses parties frequently in her fiction; see "Bliss," "Her First Ball," and "The Garden Party." See McNichol (1973) and Smith (2013).

6 Also see Beckett's “Texts for Nothing 1" which begins with "Suddenly, no, at last, long last. I couldn't anymore. I couldn't go on.... I'll describe the place, that's unimportant," also suggestive of experimental Woolf. See Beckett (1995a, b).
} 
explains, he taught her how to be stylistically economical. He was able to reveal "a whole character packed in a little phrase" (2002, p. 46). Where a novelist might take three volumes to depict a character, Shakespeare does it in an expression or a gesture.

The short story for Woolf is an open form asking questions, not offering answers. This is precisely Chekhov's method, unsettling to readers of the short stories of Thomas Hardy or Arnold Bennett where questions are always answered and certainty prevailed. The underlying pattern, the habits of mind, the surprising irresolution define the new short story generated in Bloomsbury. Vacillation, which Woolf celebrates, is the result "of an exquisitely original and fastidious taste, choosing boldly, arranging infallibly and controlled by an honesty for which we can find no match save among the Russians themselves" (1988, p. 185). As she explains in "Modern Fiction," life itself presents "question after question which must be left to sound on and on after the story is over" (2009, p. 12). Even if the stories are about nothing at all, "the horizon opens" as she writes of Chekhov in "The Russian Point of View" (1986, p. 185).

Katherine Mansfield largely shared these views, criticizing the artifice of narrative. Commenting on Somerset Maugham's "Rain," she wrote "it's too downright good a story,... too oily." She hated the resolvable and understood (like Woolf) that life isn't like that: "With all that one knows [,] how much does one not know?... The unknown is far, far greater than the known. The known is only a mere shadow" (1996, p. 165). Her motto was simple: "Risk! Risk anything!... Act for yourself. Face the truth" (1954, p. 333).

Mansfield's "At the Bay," the first in her last collection The Garden Party and Other Stories (1922), illustrates this clearly. Set in a small New Zealand rural community, it has twelve sections and no narrative arc. It is about nothing and everything with its allusions to classical literature, the Bible and even Baudelaire running throughout. But the writing is consistently vivid:

A few moments later the back door of one of the bungalows opened, and a figure in a broad-striped bathing suit flung down the paddock, cleared the stile, rushed through the tussock grass into the hollow, staggered up the sandy hillock, and raced for dear life over the big porous stones, over the cold, wet pebbles, on to the hard sand that gleamed like oil. (1998, p. 176)

The Russians, again, provide direction as they strike a balance between the immense and the trivial which Woolf develops through her treatment of detail as in "The Mark on the Wall" or the pursuit of a pencil in "A Street Haunting." For Mansfield, it could be two squares of colored glass as in "Prelude." One is blue, the other yellow. In a single sentence, Mansfield captures color, object and character through the two squares:

Kezia bent down to have one more look at a blue lawn with blue arum lilies growing at the gate, and then at a yellow lawn with yellow lilies and a yellow fence. (2005, p. 6) 
A later passage on hands again focuses on detail and form: "Exquisite were her mother's hands and the two rings she wore seemed to melt into her creamy skin" (2005, p. 25).

But Mansfield also felt that the perceptions, no matter how trivial, of the characters, should be linked to some form of context. Things and persons should not be separate or isolated: how could the reader discern their connection without some background? Everything should not be, and is not of, equal importance. Objects have different meanings, and the writer must indicate that. ${ }^{7}$ A sense of a larger whole is necessary; or as she forcefully wrote in reference to The Cherry Orchard, "it's not good enough [that] they are cutting down the cherry trees; the orchard is sold - that is really the atmosphere I want." She also wrote that "if we could only be as true to ourselves as the people in The Cherry Orchard are to themselves," then there would be hope for us. ${ }^{8}$

\section{Chekhovian Bloomsbury}

The unemotional, understated dimension of Chekov resonates throughout the Bloomsbury short story. It characterizes not only the work of Woolf and Mansfield-especially Chekhov's refusal to praise or condemn-but is also evident in the short stories of Leonard Woolf ("A Tale Told by Moonlight," or "Pearls and Swine"), E.M. Forster (see The Celestial Omnibus or The Eternal Moment) and of Vita Sackville-West (Thirty Clocks Strike the Hour and Other Stories [1932]). In these texts, the actions of individuals speak for themselves without narrative intervention. And despite criticisms by Mansfield of Chekhov's restrained emotion expressed in her reviews and journals, echoes of his work and method repeatedly appear in her writing. Chekhov's "The Name-day Party" anticipates Mansfield's "The Garden Party," while "Prelude” echoes Chekhov's “The Steppe."

Unlike Arnold Bennett, who saw his short stories replicating a material realty and one that concentrated on physical detail, or D.H. Lawrence who saw his stories as expressions of antagonism and contrast_- "Daughters of the Vicar" (1914) opposes two sisters, one who has made a respectable but stifling marriage and the other whose marriage to a miner is emotionally satisfying if financially ruinous- the Bloomsbury short story writer considers affect less significant than abstraction. The opening of Lawrence's "Fanny and Annie" (1922) restates the importance of affect as a man, destined to marry Fanny, appears at a railway station:

Flame-lurid his face as he turned among the throng of flame-lit and dark faces upon the platform. In the light of the furnace she caught sight of his drifting countenance, like a piece of floating fire. (1978, p. 458)

The opening of Woolf's "An Unwritten Novel" is the complete opposite:

\footnotetext{
7 See Mansfield (1919).

${ }^{8}$ See Mansfield $(1977,1987)$.
} 
Such an expression of unhappiness was enough by itself to make one's eyes slide above the paper's edge to the poor woman's face - insignificant without that look, almost a symbol of human destiny with it. Life's what you see in people's eyes. $(2008$, p. 18)

Lawrence shows, Woolf tells; Lawrence dramatizes, Woolf analyzes.

"Monday or Tuesday" (1921) is perhaps Woolf's most experimental and yet characteristic short story. In six paragraphs, she expands the flight of a heron into the language of the city ("Omnibuses conglomerate in conflict") and the desire for truth, interrupting the narrative curve with implied dialogue and muted action in syntax duplicating the disjunctive sights of the city:

Flaunted, leaf-light, drifting at corners, blown across the wheels, silversplashed, home or not home, gathered, scattered, squandered in separate scales, swept up, down, torn, sunk, assembled - and truth? (2008c, p. 32)

The language, syntax and even imagery echoes Gerard Manly Hopkins, while anticipating Beckett.

By the end of the final paragraph in "Monday or Tuesday," the day has done and the reader, like the implied narrator, is challenged to discover meaning with a sentence that expresses the process and value of the Bloomsbury short story in a Beckettian tone: "From ivory depths words rising shed their blackness, blossom and penetrate" (2008c, p. 32). And suddenly, as a book and flame unite, one is in an Oriental world of mystery with "minarets beneath and the India seas, while space rushes blue and stars glint-truth? or now, content with closeness" (2008c, p. 32)? The question mark underscores the unresolved nature of the story and ends with a heron again taking to the sky.

Other members of Bloomsbury Group exhibited similar stylistic practices, contributing to the formation of a Bloomsbury technique as in the case of E.M. Forster who privileges character over plot. The second sentence of "The Road from Colonus" tells us that Mr. Lucas "was perhaps reaching the age at which independence becomes valuable because it is so soon to be lost" (1985, p. 94). In the unfolding of the story of the aging Mr. Lucas and his unmarried daughter, associated in his mind with Oedipus and Antigone, "his silence was as meaningless as his speech" (1985, p. 95). But one senses his disappointment with himself, as much as with Greece. Aware that Greece is for the young, he, nonetheless, still seeks to possess it.

As Mr. Lucas rests in the crevice of a tree near a small inn discovered in a tiny Greek valley, nature prompts his rejuvenation, partly through a stream running near the inn. He re-discovers his own inner energy derived from this location. He had, writes Forster, a "perception of the coherent beauty flowering around him" which others in his party did not (1985, p. 98). Happiness, he realized, was united with locality. But his daughter and others oppose his wish to stay for a week at the hidden inn. Nevertheless, he is determined and with the aid of "silent men, murmuring water and whispering trees," he seeks permanency (1985, p. 101). But against his wishes, he is physically taken away and his flirtation with youth and energy vanishes. 
Part II of the story finds Mr. Lucas in London, subdued and submitting to the travails of middle-class life disrupted one day by receipt of asphodel bulbs from Athens wrapped in Greek newspapers. Ethel, his daughter and able to read Greek, reports of the unexpected death of the inhabitants of the Khan in Plataniste, the inn where Mr. Lucas wanted to remain, when a large tree fell on the building - the very night of the afternoon they visited. All in the building died. Ethel celebrates their escape but Mr. Lucas remains silent, his silence demonstrating a paradox attributed by Forster to Michelangelo: "Death destroys a man; the idea of Death saves him" (1985, p. 9). The modesty of action and even incomplete thoughts of Mr. Lucas do not diminish his revelation of a youth lost, of renewal frustrated, even if it means death. The impersonality of the narrator, the distancing of the voice from character, suggests the very habit of the Bloomsbury short story as seen, for example, in Woolf's “Kew Garden." In Forster's short stories, one finds a similar treatment of character and situation as in Woolf: modest, seemingly undramatic but at the same time revelatory.

\section{Bloomsbury Today}

Brevity and a lack of conclusiveness rewrite the contract between the reader and the text in the Bloomsbury short story. One finds oneself "asking questions in mid air" as Woolf writes in "Tchehov's Questions" (1987, p. 245); this, she believes, is a positive move because it is true to life. In a 1919 review of a collection of short stories by Theodore Dreiser, Woolf remarks that he lacks what she believes to be the qualities of a short story writer: "concentration, penetration, form," elements that for her, and the Bloomsbury writers, controlled their short but incisive fictional narratives which do not conclude in the way we might expect (1988, p. 87). Readers must learn to be alert because often "the tune is unfamiliar and the end a note of interrogation" (1986, p. 184).

And today? Is there an heir to the Bloomsbury short story? I mention only one, Julian Barnes (b. 1946 -), author of the novels Flaubert's Parrot and The History of the World in $101 / 2$ Chapters. Three collections of his short stories have appeared: The Lemon Table, 2004; Nothing to be Frightened of, 2008 and Pulse, 2011. "Marriage Lines," a story in Pulse, expresses the habit of people in the Western Isles of Scotland weaving their biography into the patterns on a sweater, teaching of faith and fishing, love and separation. Zig-zags on the shoulder, jagged ups and downs on the sleeves, represent the lines of marriage and life. But the narrator, a recent widower, finds no resolution of his life in the lines, only the understanding that "he was not in charge of grief. Grief was in charge of him... [and] he expected grief to teach him many other things as well" (2011, p. 127). Barnes absorbs the features of the Bloomsbury short story: restraint, understatement, quiet revelationnot only from Chekov but Woolf and Mansfield who, in a letter of January 17, 1921, set out a high bar for the Bloomsbury short story form. There "mustn't be," she wrote, "one single word out of place or one word that could be taken out. That's how I AIM at writing”(1996, p. 165). 
The Borodin Quartet, founded in 1945 in the Soviet Union, supposedly had two versions of Shostakovich's "Fourth Quartet," one strategic for government consumption, the other authentic, speaking "truth to power." 9 The Bloomsbury short story dispenses with the former and commits only to the latter. Punning on the word story, spelling it story as a floor in a building, is to think of the short "storey" as a shortening of space between levels, between the strategic and the authentic. Woolf's “The String Quartet" (1921), with its fragmented conversations that are both banal and insightful, embodies this method. The story consists of an impressionist account of a quartet's performance. Its structure duplicates the musical structure of Allegro, Moderato, Minuet and Sonata Rondo.

The Bloomsbury short story condenses the spaces between action and meaning by leaving out rather than putting in. This is significance by absence as Woolf marveled of Chekhov: "without metaphor, the feelings of his characters are related to something more important and far more remote than personal success or happiness" (1988, p. 85). The Russian writers were the determining influence on the short story writers of Bloomsbury, shaping their approach, style and technique. Detachment, dispassion and distance may at first seem to be alienating elements of the story form, but a careful reading of the Bloomsbury writers reveals a successful, if radical, aesthetic that incorporates these elements while differing from their predecessors in the substitution of the allusive or figurative for the literal.

Walking in Mrs. Richard Dalloway's garden in Westminster in Woolf's final short story, "A Summing Up," Sasha Latham asks "which view is the true one?" (Woolf $1972 \mathrm{a}, \mathrm{b}, \mathrm{p}$. 147). The question is false because we know, from reading the Bloomsbury short story, that no single view can dominate. Refracted through the imagination of these writers, all views carry value. Our responses reflect the multiplicity of vision in the Bloomsbury short story which emphasizes characters thinking and unresolved plots, plus the modernist rejection of absolutes. But Bloomsbury short stories do not end with a sense of the unfinished but the realization that life goes on and that a single solution is an artificial solution. Indeterminacy becomes the norm, a modernist gesture toward openness. Woolf's "A Haunted House" begins with "whatever hour you woke there was a door shutting" but the opposite is also true: a door opens and that door unlocks the possibilities of interpretation found in the Bloomsbury short story (Woolf 1972a, b p. 30).

Open Access This article is distributed under the terms of the Creative Commons Attribution 4.0 International License (http://creativecommons.org/licenses/by/4.0/), which permits unrestricted use, distribution, and reproduction in any medium, provided you give appropriate credit to the original author(s) and the source, provide a link to the Creative Commons license, and indicate if changes were made.

\section{References}

Barnes, Julian. 2011. Marriage lines, In Pulse. London: Jonathan Cape. 120-127.

Beckett, Samuel. 1995a. Fizzles 7: Still. In Complete short prose, ed. S.E. Gontarski, 240-242. New York: Grove Press.

\footnotetext{
9 See Denk (2016).
} 
Beckett, Samuel. 1995b. Texts for nothing, 5. In Complete Short Prose, ed. S.E. Gontarski, 117-121. New York: Grove Press.

Chan, Winnie. 2007. The economy of the short story in british periodicals of the 1890s. New York: Taylor \& Francis.

Chialant, Teresa, and Marina Lops (eds.). 2012. Time and the short story. Bern: Peter Lang.

Chesterton, G.K. 1906. Charles dickens. London: Methuen.

Denk, Jeremy. 2016 'The noise of time,' by Julian Barnes. 9 May 2016. New York Times. http://www. nytimes.com/2016/05/15/books/review/the-noise-of-time-by-julian-barnes.html. Accessed 2 August 2016.

Forster, E.M. 1985. The road to colonus. In The new collected short stories, ed. P.N. Furbank. London: Sidgwick \& Jackson.

Hunter, Adrian. 2007. The custom of fiction: Virginia woolf, the short story, the Hogarth Press. English 56: 147-169.

Lawrence, D.H. 1978. Fanny and annie. In The collected short stories, Vol. II. 458-472. London: Heinemann.

Licence, Amy. 2015. Living in squares, loving in triangles, the lives and loves of virginia wool and the bloomsbury group. Gloucestershire: Amberley, Publishing.

Mansfield, Katherine. 1954. In Journal of Katherine mansfield, ed. J. Middleton Murry. London: Constable.

Mansfield, Katherine. 1977. In Letters and journals: A selection, ed. C.K. Stead. Harmondsworth: Penguin.

Mansfield, Katherine. 1987. In The critical writings of Katherine mansfield. ed. Clare Hanson. London: Palgrave Macmillan.

Mansfield, Katherine. 1996. In The collected letters of Katherine mansfield, Vol. 4, 1920-1921. ed. Vincent O'Sullivan and Margaret Scott. Oxford: Clarendon Press.

Mansfield, Katherine. 1998. At the bay. In New Zealand stories, ed. Sel Vincent O'Sullivan. Auckland: Oxford University Press.

Mansfield, Katherine. 2005. Prelude. London: Hesperus Press.

Martin, Tim. 2014. Echo's Bones. In The telegraph, 12 April 2014. www.telegraph.co.uk/culture/ culturenews/10757089/Echos-Bones-by-Samuel-Beckett.html.Web.

McNeillie, Andrew. 1987. The essays of virginia woolf, 1919-1924 III, 113-115. San Diego: Harcourt Brace Jovanovich.

McNeillie, Andrew (ed.). 1984. In The common reader, 173-182. San Diego: Harcourt.

McNichol, Stella (ed.). 1973. Mrs. Dalloway's party: A short story sequence. San Diego: Harcourt Brace \& Company.

Randall, Bryony. 2013. Virginia woolf's idea of a party. In The modernist party, ed. Kate McLoughlin, 101-114. Edinburgh: Edinburgh University Press.

Reynier, Christine. 2003. The short story according to woolf. Journal of the Short Story in English 41: 55-67.

Rosner, Victoria. 2014. The Cambridge companion to the bloomsbury group. Cambridge: Cambridge UP.

Smith, Angela. 2013. 'Looking at the party with you': Pivotal moments in Katherine mansfield's party stories. In The modernist party, ed. Kate McLoughlin, 79-94. Edinburgh: Edinburgh University Press.

Shakespeare, William. 2002. Hamlet. In The complete Pelican Shakespeare, ed. Stephen Orgel, and R. Braunmuller, 1337-1391. London: Penguin.

Symonds, Arthur. 1899. The world as ballet. In The dance anthology, ed. Cobbett Steinberg, 346-350. New York: New American Library.

Woolf, Virginia. 1934. Walter Sickert: A conversation. London: Hogarth Press.

Woolf, Virginia. 1942. In Twelfth night at the old vic," The death of the moth and other essays. New York: Harcourt, Brace and Co. 46.

Woolf, Virginia. 1972a. A summing up. In A haunted house and oher stories, p. 147. San Diego: Harcourt Brace, Jovanovich.

Woolf, Virginia. 1972b. A haunted house. In A haunted house and other stories. San Diego: Harcourt, Brace Jovanovich. 30.

Woolf, Virginia. 1976. In The letters of virginia woolf, vol. 2 1912-1922. ed. Nigel Nicolson and Joanne Trautmann. New York: Harcourt Brace Jovanovich.

Woolf, Virginia. 1979. The letters of virginia woolf, vo. 4 1929-1931. ed. Nigel Nicolson and Joanne Trautmann. New York: Harcourt Brace Jovanovich. 
Woolf, Virginia. 1980. In Diary of virginia woolf, Vol. III, 1925-1930. ed. Anne Olivier Bell. New York: Harcourt Brace Jovanovich.

Woolf, Virginia. 1985. A sketch of the past. In Moments of being, 2nd ed, ed. Jeanne Schulkind, 64-159. San Diego: Harcourt.

Woolf, Virginia. 1986. The Russian point of view. In Essays of virginia woolf, Vol. IV. 1926-1928, ed. Andrew McNeillie, 1926-1928. London: Hogarth Press.

Woolf, Virginia. 1987. Tchehov's questions. In The essays of virginia woolf, Vol. II. 1912-1918, ed. Andrew McNeillie. New York: Harcourt Brace Jovanovich.

Woolf, Virginia. 1988. The Russian background. In The essays of virginia woolf, Vol. III, 1919-1924, ed. Andrew McNeillie, 83-86. San Diego: Harcourt, Brace, Jovanovich.

Woolf, Virginia. 2008a. Blue and green. In The mark on the wall and other short fiction, ed. David Bradshaw, 33-34. Oxford: Oxford World's Classics.

Woolf, Virginia. 2008b. The lady in the looking glass. In The mark on the wall and other short fictions, ed. David Bradshaw, 63-68. Oxford: Oxford World's Classics.

Woolf, Virginia. 2008c. Monday or Tuesday. In The mark on the wall and other short fictions, ed. David Bradshaw, 32. Oxford: Oxford World's Classics.

Woolf, Virginia. 2008d. The string quartet. In The mark on the wall and other short fiction, ed. David Bradshaw, 35-39. Oxford: Oxford World's Classics.

Woolf, Virginia. 2008e. An unwritten novel. In The mark on the wall and other short fiction, ed. David Bradshaw, 18-19. Oxford: Oxford World's Classics.

Woolf, Virginia. 2008f. In The waves, ed. Gillian Beer. Oxford: Oxford World's Classics.

Woolf, Virginia. 2009. Modern fiction. In Selected essays of virginia woolf, ed. David Bradshaw, 6-12. Oxford: Oxford World's Classics.

Ira Nadel Professor of English at the University of British Columbia, Ira Nadel is the author of biographies of Leonard Cohen, Tom Stoppard, David Mamet and Leon Uris. He has also published Joyce and the Jews, Biography: Fiction, Fact \& Form and Modernism's Second Act. He is completing a critical life of Philip Roth. 